\title{
The Discovery of LRRK2 p.R1441S, a Novel Mutation for Parkinson's Disease, Adds to the Complexity of a Mutational Hotspot
}

\section{Ignacio F. Mata, ${ }^{1,2 \dagger}$ Marie Y. Davis, ${ }^{1,2 \dagger}$ Alexis N. Lopez, ${ }^{3}$ Michael O. Dorschner, ${ }^{4,5}$ Erica Martinez, ${ }^{1}$ Dora Yearout, ${ }^{1,2}$ Brenna A. Cholerton, ${ }^{1,4}$ Shu-Ching Hu, ${ }^{1,2}$ Karen L. Edwards, ${ }^{6}$ Thomas D. Bird, ${ }^{1,2}$ and Cyrus P. Zabetian ${ }^{1,2 *}$}

\author{
${ }^{1}$ Veterans Affairs Puget Sound Health Care System, Seattle, Washington \\ ${ }^{2}$ Department of Neurology, University of Washington School of Medicine, Seattle, Washington \\ ${ }^{3}$ Department of Medicine, University of Michigan, Ann Arbor, Michigan \\ ${ }^{4}$ Department of Psychiatry and Behavioral Sciences, University of Washington, Seattle, Washington \\ ${ }^{5}$ Department of Pathology, University of Washington, Seattle, Washington \\ ${ }^{6}$ Department of Epidemiology, University of California, Irvine, California
}

Manuscript Received: 15 March 2016; Manuscript Accepted: 8 April 2016

Mutations in the LRRK2 gene result in autosomal dominant, late onset Parkinson's disease (PD). Three such mutations (p.R1441C, p.R1441G, and p.R1441H) are known to occur within codon 1441, and haplotype analyses indicate that each one has arisen independently on multiple occasions. We sequenced the entire coding region of 18 casual genes for PD or other parkinsonian neurodegenerative disorders in the proband of a family with autosomal dominant PD. We discovered a new missense mutation in the LRRK2 gene, c.4321C $>\mathrm{A}$ (p.R1441S). The mutation was predicted to be highly deleterious in silico (Combined Annotation Dependent Depletion score of 25.5) and segregated with disease in the pedigree. The clinical characteristics of affected family members were similar to those described in PD families with other mutations in LRRK2 codon 1441 and included resting tremor, rigidity, bradykinesia, unilateral onset, and a good response to levodopa. Age at onset ranged from 41 to 76. Two of the affected members of the pedigree underwent detailed, longitudinal neuropsychological testing, and both displayed evidence of mild cognitive deficits at or slightly preceding the onset of motor symptoms. LRRK2 p.R1441S represents the fourth pathogenic mutation observed within codon 1441 and its discovery adds to the remarkable complexity of a mutational hotspot within the ROC domain of the LRRK2 protein.

(c) 2016 Wiley Periodicals, Inc.

Key words: movement disorders; genetics; neuropsychological

\section{INTRODUCTION}

Parkinson's disease (PD; MIM 168600) is the second most common neurodegenerative disorder and is characterized by bradykinesia, rigidity, resting tremor, and postural instability.
How to Cite this Article:

Mata IF, Davis MY, Lopez AN, Dorschner MO, Martinez E, Yearout D, Cholerton BA, Hu S-C, Edwards KL, Bird TD, Zabetian CP. 2016. The Discovery of LRRK2 p.R1441S, a Novel Mutation for Parkinson's Disease, Adds to the Complexity of a Mutational Hotspot. Am J Med Genet Part B 171B:925-930.

These motor features are frequently accompanied by a number of non-motor problems including cognitive dysfunction. Approximately, 20\% of PD patients report a family history of the disease and over the past two decades eight causal genes for clinically typical early and late-onset PD (SNCA, PARK2 [parkin], PINK1, PARK7 [DJ-1], LRRK2, VPS35, DNAJC13, RAB39B) have been

'Ignacio F. Mata and Marie Y. Davis contributed equally to this work. Conflicts of interest: None.

Disclaimer: The contents do not represent the views of the U.S. Department of Veterans Affairs or the United States Government.

Grant sponsor: Department of Veterans Affairs (Merit Award); Grant number: \#1I01BX000531; Grant sponsor: National Institutes of Health; Grant numbers: R01 NS065070, P50 NS062684.

*Correspondence to:

Dr. Cyrus P. Zabetian, VA Puget Sound Health Care System, GRECC S-182, 1660 South Columbian Way, Seattle, WA 98108.

E-mail: zabetian@u.washington.edu

Article first published online in Wiley Online Library

(wileyonlinelibrary.com): 25 April 2016

DOI 10.1002/ajmg.b.32452 
identified [Polymeropoulos et al., 1997; Kitada et al., 1998; Bonifati et al., 2003; Paisan-Ruiz et al., 2004; Valente et al., 2004; Zimprich et al., 2004, 2011; Vilarino-Guell et al., 2011, 2014; Mata et al., 2015].

Among patients with disease-causing variants in a known gene, LRRK2 mutations are the most common. Less than 10 LRRK2 mutations are generally considered pathogenic [Paisan-Ruiz et al., 2013]. Of these, p.G2019S is by far the most prevalent and occurs at a frequency of approximately $1 \%$ in PD patients of European origin [Healy et al., 2008]. The next most common LRRK2 mutations occur within codon 1441; p.R1441C, p.R1441G, and p.R1441H [Paisan-Ruiz et al., 2004; Zimprich et al., 2004; Zabetian et al., 2005]. Haplotype analyses suggest that each of these three mutations arose independently on multiple occasions, indicating that this region of the gene is a mutational "hotspot" [Haugarvoll et al., 2008; Mata et al., 2009a; Ross et al., 2009]. Codon 1441 mutations are highly penetrant and result in late-onset PD that is clinically indistinguishable from idiopathic PD [Haugarvoll et al., 2008; Ruiz-Martinez et al., 2010].

In this study, we report a new mutation in LRRK2 codon 1441 (p.R1441S) which segregates with disease in a multiplex PD family, and describe the clinical characteristics of affected members of the pedigree.

\section{MATERIALS AND METHODS}

\section{Subjects}

All available members of the family were enrolled in the Parkinson's Genetic Research Study at the VA Puget Sound Health Care System (VAPSHCS). These individuals underwent a detailed examination and interview by a study neurologist (Fig. 1: family members II-2, II-3, and II-4). Two affected members of the family (II-2 and II-3) also underwent detailed cognitive testing through concurrent enrollment in the Pacific Northwest Udall Center. These subjects

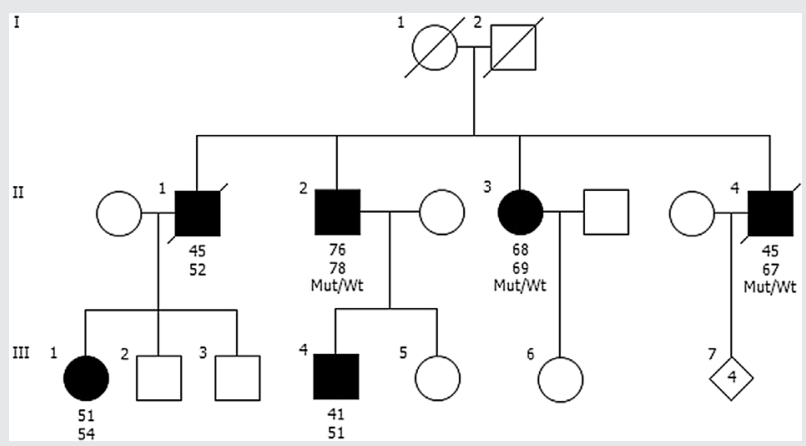

FIG. 1. Pedigree diagram of family with LRRK2 p.R1441S. Individuals affected with Parkinson's disease are represented with black symbols, unaffected individuals with open symbols. Age at onset is indicated immediately below each symbol, followed by age at last clinical evaluation (II-2, II-3), age at death (II-1, II-4), or current age (III-1, III-4). Wt, wild-type; Mut, mutation (p.R1441S). were assigned a diagnosis of no cognitive impairment, mild cognitive impairment (MCI), or dementia using previously described procedures [Cholerton et al., 2013]. The institutional review boards of the University of Washington and VAPSHCS approved the study and all participants provided informed consent.

\section{Genetic Analysis}

Genomic DNA was extracted from peripheral blood samples using standard techniques. Initially (in 2005), all 51 exons of the LRRK2 gene (including intron/exon boundaries) were Sanger-sequenced in the proband using previously described methods [Zabetian et al., 2009]. Subsequently, when next generation sequencing (NGS) technology became available, the proband was screened for mutations within the coding region of 18 casual genes for PD or other neurodegenerative disorders in which parkinsonism has been reported (ATP13A2, DNAJC13, EIF4G1, FBXO7, GIGYF2, GRN, LRRK2, MAPT, PARK2, PARK7, PINK1, PLA2G6, RAB39B, SNCA, TARDBP, TH, VCP, and VPS35). Briefly, targeted NGS was performed as follows. Sample libraries were constructed and enriched for the genes of interest using $x G e n$ custom probes (Integrated DNA Technologies, Coralville, IA). The enriched libraries were sequenced with 100-nucleotide paired-end reads on a HiSeq2500 (Illumina, San Diego, CA) to achieve a mean coverage of $>100 \mathrm{X}$. The resulting sequences were aligned to the human genome reference (hg19). We excluded those variants that did not meet standard quality values, had a minor allele frequency $>1 \%$ in the Exome Aggregation Consortium (ExAC) database (http://exac.broadinstitute.org), or were classified as low impact by SnpEff prediction tools [Cingolani et al., 2012]. In addition, SNCA, PARK2, PINK1, and PARK7 were screened for copy number variation using multiplex ligation-dependent probe amplification (MLPA; MRC-Holland, Amsterdam, Netherlands) as previously described [Cornejo-Olivas et al., 2015].

\section{RESULTS}

\section{Clinical Description}

The proband (II-4), a male veteran who worked as a welder, developed a resting tremor of the left foot at age 45 . By age 48 , all cardinal motor features were present on examination (Table I). He displayed a good response to dopamine replacement therapy throughout the course of the disease; treatment included dopamine agonists (bromocriptine, pergolide, and pramipexole), trihexyphenidyl, and up to 2,750 mg of levodopa per day. By age 65, he was wheelchair-bound and resided at a skilled nursing facility. On examination at age 66, he had severe dyskinesias and motor fluctuations, and dopamine dysregulation syndrome characterized by severe anxiety with wearing off. He also developed visual hallucinations, which were briefly treated with olanzapine. A brain MRI was unremarkable. Detailed cognitive testing was never performed, but Mini-Mental State Examination (MMSE) score was $26 / 28$ at age 66 , and $27 / 28$ at age 67 (writing tasks were not attempted due to severe tremor). He died at age 67 due to complications from pneumonia.

The proband's brother (II-2), a veteran with Agent Orange exposure, did not display signs or report symptoms of parkinsonism 
TABLE I. Clinical Characteristics of Affected Members of the

$$
\text { Pedigree }
$$

\begin{tabular}{|c|c|c|c|}
\hline \multirow[b]{2}{*}{ Characteristic } & \multicolumn{3}{|c|}{ Patient } \\
\hline & $\|-2$ & II-3 & II-4 \\
\hline Sex & M & $\mathrm{F}$ & M \\
\hline Age at onset, year & 76 & 68 & 45 \\
\hline Age at last evaluation, year & 78 & 69 & 67 \\
\hline Age at death, year & - & - & 67 \\
\hline Bradykinesia & Y & Y & Y \\
\hline Rigidity & Y & Y & Y \\
\hline Resting tremor & Y & Y & Y \\
\hline Postural instability & $\mathrm{N}$ & Y & Y \\
\hline Unilateral onset & Y & Y & Y \\
\hline Levodopa response & Y & Y & Y \\
\hline Levodopa-induced dyskinesia & $\mathrm{N}$ & $\mathrm{N}$ & Y \\
\hline Hoehn and Yahr stage ${ }^{a}$ & 2 & 3 & 5 \\
\hline MDS-UPDRS III score & 26 & 27 & NA \\
\hline Visual hallucinations & $\mathrm{N}$ & $\mathrm{N}$ & Y \\
\hline Cognitive status $^{a}$ & $\mathrm{MCl}$ & $\mathrm{MCl}$ & NA \\
\hline
\end{tabular}

MCI, mild cognitive impairment; MDS-UPDRS III, Movement Disorder Society Unified Parkinson's Disease Rating Scale Part III; NA, not available.

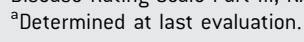

at the time of study enrollment at age 73. At his second study assessment at age 75 , he was still not aware of any motor symptoms but on examination was found to have slight bradykinesia and rigidity of the right upper and lower extremity, and hypomimia. He reported a slight decline in cognition and displayed mild deficits on neuropsychological testing. He was classified as having MCI together with possible undiagnosed, early PD. At age 76, he noticed an intermittent resting tremor of his right hand and sought care from a community neurologist who diagnosed him with PD. ${ }^{123}$ I-ioflupane (DaTscan) SPECT showed moderately to severely decreased uptake in the bilateral putamina, and mildly decreased uptake in the right caudate. He was started on levodopa shortly thereafter with a marked improvement in motor symptoms. At his third research assessment at age 78 in the "on" state, he displayed bilateral bradykinesia and rigidity (more pronounced on the right), and a slight resting tremor of the right upper extremity, but no postural instability or dyskinesias. There was little change in his performance on cognitive testing and he was again diagnosed with MCI.

The proband's sister (II-3) did not display signs or report symptoms of parkinsonism at the time of study enrollment (age 67) or 1 year later at the second study visit. However, neuropsychological testing at the second visit revealed mild to moderate deficits on tests representing multiple cognitive domains and she was diagnosed with MCI. At age 68, she noticed an intermittent resting tremor of her left hand and several months later was diagnosed with PD by a community neurologist. She was started on levodopa at the time of diagnosis and later reported a marked improvement in motor symptoms. A brain MRI showed evidence of moderate chronic small vessel ischemic disease but was otherwise unremarkable. At her third research assessment at age 69 in the "on" state, she displayed bilateral bradykinesia and rigidity (more pronounced on the left), a slight resting tremor of the left upper extremity, and postural instability, but no dyskinesias. Her overall performance on neuropsychological testing was stable and her cognitive diagnosis remained MCI.

Three other members of the pedigree have been diagnosed with PD by community neurologists: the patient's oldest brother (II-1) who is now deceased, and his niece (III-1) and nephew (III-4). However, little clinical information and no DNA was available for these individuals. The proband's mother and father died at ages 93 and 75, respectively, and to the family's knowledge, neither one displayed signs of parkinsonism before death.

The family is of European origin and reports that their ancestors emigrated from Germany, England, and Scotland.

\section{Genetic Findings}

Sanger sequencing of the full $L R R K 2$ coding region in the proband revealed a novel missense mutation, c.4321C $>$ A (p.R1441S). This variant was not observed in more than 60,000 exomes included in the ExAC database. The amino acid Arg1441 is highly conserved across species and this mutation is predicted to be deleterious as evidenced by a Combined Annotation Dependent Depletion (CADD) [Kircher et al., 2014] score of 25.5 (Fig. 2). Subsequent screening of the proband for 18 causal genes for parkinsonian neurodegenerative disorders using NGS did not reveal any other pathogenic mutations. No copy number variations within $S N C A$, PARK2, PINK1, and PARK7 were detected in the proband by MLPA. Targeted genotyping of the remainder of the pedigree revealed that both of the proband's affected siblings were heterozygous for LRRK2 p.R1441S (Fig. 1).

\section{DISCUSSION}

We have identified a new mutation (p.R1441S) in the LRRK2 gene in a multiplex family with clinically typical PD. We propose that this mutation is pathogenic because it: (i) lies within a codon in which three known pathogenic mutations occur; (ii) is predicted to be deleterious in silico; and (iii) appears to segregate with disease in the pedigree (Fig. 1). Furthermore, the proband did not harbor pathogenic mutations in any other established PD genes.

The frequency and geographic distribution of the three previously described mutations within codon 1441 vary considerably, but the origins of all three are characterized by multiple founding events. p.R1441C is the most common and is widely distributed in populations of European origin but has also been reported in an Asian PD patient [Haugarvoll et al., 2008]. Its frequency is typically well below $1 \%$ in unselected PD cohorts, but frequencies of $2-4 \%$ have been reported in Belgium and Southern Italy [Nuytemans et al., 2008; Criscuolo et al., 2011]. Haplotype analyses suggest that p.R1441C has arisen independently on at least four separate occasions [Haugarvoll et al., 2008]. p.R1441G occurs at a frequency of $22 \%$ in PD patients from the Basque population of Spain [Gorostidi et al., 2009], where a common founding event is believed to have occurred in the seventh century [Mata et al., 2009b]. However, only four PD families with this mutation have been reported outside of Spain, and two of them did not share the 


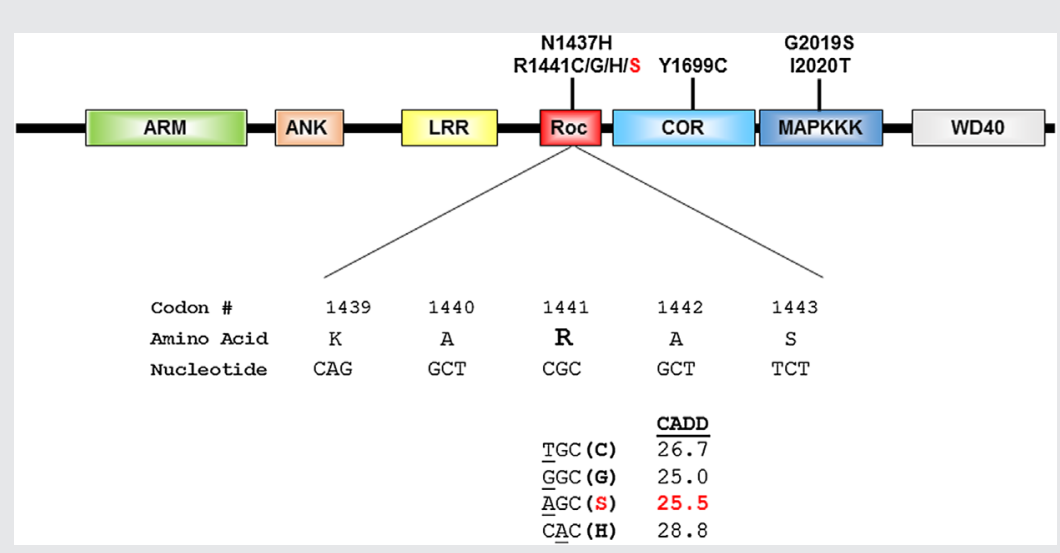

FIG. 2. Schematic diagram of LRRK2 and codon 1441 mutations. The functional domains of LRRK2 are depicted [top] together with the location of well-established pathogenic mutations for Parkinson's disease. The nucleotide (underlined) and corresponding amino change resulting from each of the four mutations that occur in codon 1441 are displayed (bottom), along with the Combined Annotation Dependent Depletion (CADD) score for each mutation.

haplotype observed among all Basque mutation carriers [Mata et al., 2009a,b; Yescas et al., 2010; Hatano et al., 2014]. Finally, p.R1441H has been reported in a handful of PD families in Europe, North America, and Asia, but an analysis of four such families indicated that none of them shared a common haplotype with one another [Ross et al., 2009]. Thus, taken together with our discovery of p.R1441S, these data indicate that over 10 independent mutational events have occurred within codon 1441.

The reason why $L R R K 2$ codon 1441 is highly mutable is not entirely clear, but a likely contributing factor is the presence of a CpG dinucleotide (Fig. 2). In mammals, the $\mathrm{C}$ residues of most CpGs are methylated which promotes the deamination of $\mathrm{C}$, resulting in a T:G mismatch [Ehrlich and Wang, 1981]. Consequently, methyl-CpGs mutate at a rate 10-50 times that of Cs in any other context or of any other nucleotide [Coulondre et al., 1978; Hwang and Green, 2004]. Thus, over time, CpG dinucleotides are replaced by TpGs and CpAs [Walser and Furano, 2010]. This phenomenon might influence the occurrence of two of the four missense mutations observed at codon 1441, p.R1441C (c.4321C > T), and p.R1441H (c.4322G >A) (Fig. 2).

The clinical characteristics of our family with p.R1441S are generally similar to those reported in PD patients with other mutations in codon 1441. Resting tremor is the initial symptom in most patients with p.R1441C and p.R1441G [Simon-Sanchez et al., 2006; Haugarvoll et al., 2008], and all three affected individuals in our family also presented with resting tremor. Patients with p.R1441C and p.R1441G typically have asymmetry at onset and a good response to levodopa [Simon-Sanchez et al., 2006; Haugarvoll et al., 2008], as did the affected members of our pedigree. Age at onset in PD patients who carry mutations in codon 1441 ranges from 30 to 79 [Haugarvoll and Wszolek, 2009]. In our pedigree, age at onset varied from 41 to 76 , but a similarly wide range in onset has been reported within individual families with p.R1441C and p.R1441G [Paisan-Ruiz et al., 2005; Nuytemans et al., 2008]. Penetrance estimates are $>90 \%$ at age 75 for p.R1441C and $83 \%$ at age 80 for p.R1441G [Haugarvoll et al., 2008; RuizMartinez et al., 2010]. The pattern observed in our pedigree in consistent with a similarly high rate of penetrance. Finally, crosssectional studies suggest that PD patients with LRRK2 p.G2019S exhibit a slower decline in cognitive function [Alcalay et al., 2015; Srivatsal et al., 2015] than non-carriers, but there are conflicting data as to whether the same is true for patients with p.R1441G [Estanga et al., 2014; Somme et al., 2015]. In the two affected members of our pedigree who underwent detailed neuropsychological testing, mild cognitive deficits were observed at or slightly preceding the onset of motor symptoms. However, in unselected PD cohorts $19-24 \%$ of patients meet criteria for MCI at the time of diagnosis [Muslimovic et al., 2008; Aarsland et al., 2009]. Determining the trajectory of cognitive decline in the affected members of our pedigree will require further longitudinal assessments.

The mechanism by which mutations in LRRK2 codon 1441 result in neurodegeneration has been studied for over a decade and is slowly being elucidated. Codon 1441 is located in the Ras of complex proteins (ROC) domain of LRRK2. The ROC domain is an active GTPase and is thought to regulate LRRK2 kinase activity [Guo et al., 2007]. In vitro experiments suggest that the p.R1441H mutation causes a twofold reduction in GTPase activity and a twofold increase in GTP-binding affinity, thus, trapping the ROC domain in a more persistent active state [Liao et al., 2014]. This results in overactivation of the LRRK2 kinase domain, which mediates neuronal toxicity [Smith et al., 2006].

In conclusion, we have identified a novel LRRK2 variant (p.R1441S), which segregates with disease in a multiplex PD family and represents the fourth pathogenic mutation observed within codon 1441. The clinical characteristics of the affected family members are similar to those described in PD families with other codon 1441 mutations. The discovery of p.R1441S adds to the unusual diversity of a mutational hotspot within the ROC domain of the LRRK2 protein. 


\section{ACKNOWLEDGMENTS}

This work was supported by grants from the Department of Veterans Affairs (Merit Award \#1I01BX000531) and National Institutes of Health (R01 NS065070, P50 NS062684). We thank all of the individuals who participated in the study.

\section{REFERENCES}

Aarsland D, Bronnick K, Larsen JP, Tysnes OB, Alves G, Norwegian ParkWest Study G. 2009. Cognitive impairment in incident, untreated Parkinson disease: The Norwegian ParkWest study. Neurology 72(13): 1121-1126.

Alcalay RN, Mejia-Santana H, Mirelman A, Saunders-Pullman R, Raymond D, Palmese C, Caccappolo E, Ozelius L, Orr-Urtreger A, Clark L, Giladi N, Bressman S, Marder K, Consortium LAJ. 2015. Neuropsychological performance in LRRK2 G2019S carriers with Parkinson's disease. Parkinsonism Relat Disord 21(2):106-110.

Bonifati V, Rizzu P, van Baren MJ, Schaap O, Breedveld GJ, Krieger E, Dekker MC, Squitieri F, Ibanez P, Joosse M, van Dongen JW, Vanacore N, van Swieten JC, Brice A, Meco G, van Duijn CM, Oostra BA, Heutink P. 2003. Mutations in the DJ-1 gene associated with autosomal recessive early-onset parkinsonism. Science 299(5604):256-259.

Cholerton BA, Zabetian CP, Quinn JF, Chung KA, Peterson A, Espay AJ, Revilla FJ, Devoto J, Watson GS, Hu SC, Edwards KL, Montine TJ, Leverenz JB. 2013. Pacific Northwest Udall Center of excellence clinical consortium: Study design and baseline cohort characteristics. J Parkinsons Dis 3(2):205-214.

Cingolani P, Platts A, Wang le L, Coon M, Nguyen T, Wang L, Land SJ, Lu X, Ruden DM. 2012. A program for annotating and predicting the effects of single nucleotide polymorphisms, SnpEff: SNPs in the genome of Drosophila melanogaster strain w1118; iso-2; iso-3. Fly (Austin) 6(2):80-92.

Cornejo-Olivas MR, Torres L, Mata IF, Mazzetti P, Rivas D, Cosentino C, Inca-Martinez M, Cuba JM, Zabetian CP, Leverenz JB. 2015. A Peruvian family with a novel PARK2 mutation: Clinical and pathological characteristics. Parkinsonism Relat Disord 21(5):444-448.

Coulondre C, Miller JH, Farabaugh PJ, Gilbert W. 1978. Molecular basis of base substitution hotspots in Escherichia coli. Nature 274(5673): 775-780.

Criscuolo C, De Rosa A, Guacci A, Simons EJ, Breedveld GJ, Peluso S, Volpe G, Filla A, Oostra BA, Bonifati V, De Michele G. 2011. The LRRK2 R1441C mutation is more frequent than G2019S in Parkinson's disease patients from southern Italy. Mov Disord 26(9):1733-1736.

Ehrlich M, Wang RY. 1981. 5-Methylcytosine in eukaryotic DNA. Science 212(4501):1350-1357.

Estanga A, Rodriguez-Oroz MC, Ruiz-Martinez J, Barandiaran M, Gorostidi A, Bergareche A, Mondragon E, Lopez de Munain A, Marti-Masso JF. 2014. Cognitive dysfunction in Parkinson's disease related to the R1441G mutation in LRRK2. Parkinsonism Relat Disord 20(10):1097-1100.

Gorostidi A, Ruiz-Martinez J, Lopez de Munain A, Alzualde A, Marti Masso JF. 2009. LRRK2 G and R1441G mutations associated with Parkinson's disease are common in the Basque Country, but relative prevalence is determined by ethnicity. Neurogenetics 10(2): 157159.

Guo L, Gandhi PN, Wang W, Petersen RB, Wilson-Delfosse AL, Chen SG. 2007. The Parkinson's disease-associated protein, leucine-rich repeat kinase 2 (LRRK2), is an authentic GTPase that stimulates kinase activity. Exp Cell Res 313(16):3658-3670.
Hatano T, Funayama M, Kubo S, Mata IF, Oji Y, Mori A, Zabetian CP, Waldherr SM, Yoshino H, Oyama G, Shimo Y, Fujimoto K, Oshima H, Kunii Y, Yabe H, Mizuno Y, Hattori N. 2014. Identification of a Japanese family with LRRK2 p.R1441G-related Parkinson's disease. Neurobiol Aging 35(11):2656; e17-23.

Haugarvoll K, Rademakers R, Kachergus JM, Nuytemans K, Ross OA, Gibson JM, Tan EK, Gaig C, Tolosa E, Goldwurm S, Guidi M, Riboldazzi G, Brown L, Walter U, Benecke R, Berg D, Gasser T, Theuns J, Pals P, Cras P, De Deyn PP, Engelborghs S, Pickut B, Uitti RJ, Foroud T, Nichols WC, Hagenah J, Klein C, Samii A, Zabetian CP, Bonifati V, Van Broeckhoven C, Farrer MJ, Wszolek ZK. 2008. Lrrk2 R1441C parkinsonism is clinically similar to sporadic Parkinson disease. Neurology 70(16 Pt 2):1456-1460.

Haugarvoll K, Wszolek ZK. 2009. Clinical features of LRRK2 parkinsonism. Parkinsonism Relat Disord 15(Suppl 3):S205-S208.

Healy DG, Falchi M, O'Sullivan SS, Bonifati V, Durr A, Bressman S, Brice A, Aasly J, Zabetian CP, Goldwurm S, Ferreira JJ, Tolosa E, Kay DM, Klein C, Williams DR, Marras C, Lang AE, Wszolek ZK, Berciano J, Schapira AH, Lynch T, Bhatia KP, Gasser T, Lees AJ, Wood NW. 2008. Phenotype, genotype, and worldwide genetic penetrance of LRRK2associated Parkinson's disease: A case-control study. Lancet Neurol 7(7):583-590

Hwang DG, Green P. 2004. Bayesian Markov chain Monte Carlo sequence analysis reveals varying neutral substitution patterns in mammalian evolution. Proc Natl Acad Sci USA 101(39):13994-14001.

Kircher M, Witten DM, Jain P, O’Roak BJ, Cooper GM, Shendure J. 2014. A general framework for estimating the relative pathogenicity of human genetic variants. Nat Genet 46(3):310-315.

Kitada T, Asakawa S, Hattori N, Matsumine H, Yamamura Y, Minoshima S, Yokochi M, Mizuno Y, Shimizu N. 1998. Mutations in the parkin gene cause autosomal recessive juvenile parkinsonism. Nature 392(6676): 605-608.

Liao J, Wu CX, Burlak C, Zhang S, Sahm H, Wang M, Zhang ZY, Vogel KW, Federici M, Riddle SM, Nichols RJ, Liu D, Cookson MR, Stone TA, Hoang QQ. 2014. Parkinson disease-associated mutation R1441H in LRRK2 prolongs the "active state" of its GTPase domain. Proc Natl Acad Sci USA 111(11):4055-4060.

Mata IF, Cosentino C, Marca V, Torres L, Mazzetti P, Ortega O, Raggio V, Aljanati R, Buzo R, Yearout D, Dieguez E, Zabetian CP. 2009a. LRRK2 mutations in patients with Parkinson's disease from Peru and Uruguay. Parkinsonism Relat Disord 15(5):370-373.

Mata IF, Hutter CM, Gonzalez-Fernandez MC, de Pancorbo MM, Lezcano E, Huerta C, Blazquez M, Ribacoba R, Guisasola LM, Salvador C, Gomez-Esteban JC, Zarranz JJ, Infante J, Jankovic J, Deng H, Edwards KL, Alvarez V, Zabetian CP. 2009b. Lrrk2 R1441G-related Parkinson's disease: Evidence of a common founding event in the seventh century in Northern Spain. Neurogenetics 10(4):347-353.

Mata IF, Jang Y, Kim CH, Hanna DS, Dorschner MO, Samii A, Agarwal P, Roberts JW, Klepitskaya O, Shprecher DR, Chung KA, Factor SA, Espay AJ, Revilla FJ, Higgins DS, Litvan I, Leverenz JB, Yearout D, Inca-Martinez $\mathrm{M}$, Martinez $\mathrm{E}$, Thompson TR, Cholerton BA, Hu SC, Edwards KL, Kim KS, Zabetian CP. 2015. The RAB39B p.G192R mutation causes X-linked dominant Parkinson's disease. Mol Neurodegener 10(1):50.

Muslimovic D, Post B, Speelman JD, Schmand B, de Haan RJ, Group CS. 2008. Determinants of disability and quality of life in mild to moderate Parkinson disease. Neurology 70(23):2241-2247.

Nuytemans K, Rademakers R, Theuns J, Pals P, Engelborghs S, Pickut B, de Pooter T, Peeters K, Mattheijssens M, Van den Broeck M, Cras P, De Deyn PP, van Broeckhoven C. 2008. Founder mutation p.R1441C in the leucine-rich repeat kinase 2 gene in Belgian Parkinson's disease patients. Eur J Hum Genet 16(4):471-479. 
Paisan-Ruiz C, Jain S, Evans EW, Gilks WP, Simon J, van der Brug M, de Munain AL, Aparicio S, Gil AM, Khan N, Johnson J, Martinez JR, Nicholl D, Carrera IM, Pena AS, de Silva R, Lees A, Marti-Masso JF, Perez-Tur J, Wood NW, Singleton AB. 2004. Cloning of the gene containing mutations that cause PARK8-linked Parkinson's disease. Neuron 44(4):595600 .

Paisan-Ruiz C, Lewis PA, Singleton AB. 2013. LRRK2: Cause, risk, and mechanism. J Parkinsons Dis 3(2):85-103.

Paisan-Ruiz C, Saenz A, Lopez de Munain A, Marti I, Martinez Gil A, Marti-Masso JF, Perez-Tur J. 2005. Familial Parkinson's disease: Clinical and genetic analysis of four Basque families. Ann Neurol 57(3):365-372.

Polymeropoulos MH, Lavedan C, Leroy E, Ide SE, Dehejia A, Dutra A, Pike B, Root H, Rubenstein J, Boyer R, Stenroos ES, Chandrasekharappa S, Athanassiadou A, Papapetropoulos T, Johnson WG, Lazzarini AM, Duvoisin RC, Di Iorio G, Golbe LI, Nussbaum RL. 1997. Mutation in the alpha-synuclein gene identified in families with Parkinson's disease. Science 276(5321):2045-2047.

Ross OA, Spanaki C, Griffith A, Lin CH, Kachergus J, Haugarvoll K, Latsoudis H, Plaitakis A, Ferreira JJ, Sampaio C, Bonifati V, Wu RM, Zabetian CP, Farrer MJ. 2009. Haplotype analysis of Lrrk2 R1441H carriers with parkinsonism. Parkinsonism Relat Disord 15(6):466-467.

Ruiz-Martinez J, Gorostidi A, Ibanez B, Alzualde A, Otaegui D, Moreno F, Lopez de Munain A, Bergareche A, Gomez-Esteban JC, Marti Masso JF. 2010. Penetrance in Parkinson's disease related to the LRRK2 R1441G mutation in the Basque country (Spain). Mov Disord 25(14):2340-2345.

Simon-Sanchez J, Marti-Masso JF, Sanchez-Mut JV, Paisan-Ruiz C, Martinez-Gil A, Ruiz-Martinez J, Saenz A, Singleton AB, Lopez de Munain A, Perez-Tur J. 2006. Parkinson's disease due to the R1441G mutation in Dardarin: A founder effect in the Basques. Mov Disord 21(11):1954-1959.

Smith WW, Pei Z, Jiang H, Dawson VL, Dawson TM, Ross CA. 2006. Kinase activity of mutant LRRK2 mediates neuronal toxicity. Nat Neurosci 9(10):1231-1233.

Somme JH, Molano Salazar A, Gonzalez A, Tijero B, Berganzo K, Lezcano E, Fernandez Martinez M, Zarranz JJ, Gomez-Esteban JC. 2015. Cognitive and behavioral symptoms in Parkinson's disease patients with the $\mathrm{G}$ and R1441G mutations of the LRRK2 gene. Parkinsonism Relat Disord 21(5):494-499.

Srivatsal S, Cholerton B, Leverenz JB, Wszolek ZK, Uitti RJ, Dickson DW, Weintraub D, Trojanowski JQ, Van Deerlin VM, Quinn JF, Chung KA, Peterson AL, Factor SA, Wood-Siverio C, Goldman JG, Stebbins GT, Bernard B, Ritz B, Rausch R, Espay AJ, Revilla FJ, Devoto J, Rosenthal LS, Dawson TM, Albert MS, Mata IF, Hu SC, Montine KS, Johnson C, Montine TJ, Edwards KL, Zhang J, Zabetian CP. 2015. Cognitive profile of LRRK2-related Parkinson's disease. Mov Disord 30(5):728-733.

Valente EM, Abou-Sleiman PM, Caputo V, Muqit MM, Harvey K, Gispert S, Ali Z, Del Turco D, Bentivoglio AR, Healy DG, Albanese A, Nussbaum R, Gonzalez-Maldonado R, Deller T, Salvi S, Cortelli P, Gilks WP,
Latchman DS, Harvey RJ, Dallapiccola B, Auburger G, Wood NW. 2004. Hereditary early-onset Parkinson's disease caused by mutations in PINK1. Science 304(5674):1158-1160.

Vilarino-Guell C, Rajput A, Milnerwood AJ, Shah B, Szu-Tu C, Trinh J, Yu I, Encarnacion M, Munsie LN, Tapia L, Gustavsson EK, Chou P, Tatarnikov I, Evans DM, Pishotta FT, Volta M, Beccano-Kelly D, Thompson C, Lin MK, Sherman HE, Han HJ, Guenther BL, Wasserman WW, Bernard V, Ross CJ, Appel-Cresswell S, Stoessl AJ, Robinson CA, Dickson DW, Ross OA, Wszolek ZK, Aasly JO, Wu RM, Hentati F, Gibson RA, McPherson PS, Girard M, Rajput M, Rajput AH, Farrer MJ. 2014. DNAJC13 mutations in Parkinson disease. Hum Mol Genet 23(7):1794-1801.

Vilarino-Guell C, Wider C, Ross OA, Dachsel JC, Kachergus JM, Lincoln SJ, Soto-Ortolaza AI, Cobb SA, Wilhoite GJ, Bacon JA, Behrouz B, Melrose HL, Hentati E, Puschmann A, Evans DM, Conibear E, Wasserman WW, Aasly JO, Burkhard PR, Djaldetti R, Ghika J, Hentati F, Krygowska-Wajs A, Lynch T, Melamed E, Rajput A, Rajput AH, Solida A, Wu RM, Uitti RJ, Wszolek ZK, Vingerhoets F, Farrer MJ. 2011. VPS35 mutations in Parkinson disease. Am J Hum Genet 89(1):162-167.

Walser JC, Furano AV. 2010. The mutational spectrum of non-CpG DNA varies with CpG content. Genome Res 20(7):875-882.

Yescas P, Lopez M, Monroy N, Boll MC, Rodriguez-Violante M, Rodriguez U, Ochoa A, Alonso ME. 2010. Low frequency of common LRRK2 mutations in Mexican patients with Parkinson's disease. Neurosci Lett 485(2):79-82.

Zabetian CP, Samii A, Mosley AD, Roberts JW, Leis BC, Yearout D, Raskind WH, Griffith A. 2005. A clinic-based study of the LRRK2 gene in Parkinson disease yields new mutations. Neurology 65(5): $741-744$

Zabetian CP, Yamamoto M, Lopez AN, Ujike H, Mata IF, Izumi Y, Kaji R, Maruyama H, Morino H, Oda M, Hutter CM, Edwards KL, Schellenberg GD, Tsuang DW, Yearout D, Larson EB, Kawakami H. 2009. LRRK2 mutations and risk variants in Japanese patients with Parkinson's disease. Mov Disord 24(7):1034-1041.

Zimprich A, Benet-Pages A, Struhal W, Graf E, Eck SH, Offman MN, Haubenberger D, Spielberger S, Schulte EC, Lichtner P, Rossle SC, Klopp N, Wolf E, Seppi K, Pirker W, Presslauer S, Mollenhauer B, Katzenschlager R, Foki T, Hotzy C, Reinthaler E, Harutyunyan A, Kralovics R, Peters A, Zimprich F, Brucke T, Poewe W, Auff E, Trenkwalder C, Rost B, Ransmayr G, Winkelmann J, Meitinger T, Strom TM. 2011. A mutation in VPS35, encoding a subunit of the retromer complex, causes late-onset Parkinson disease. Am J Hum Genet 89(1):168-175.

Zimprich A, Biskup S, Leitner P, Lichtner P, Farrer M, Lincoln S, Kachergus J, Hulihan M, Uitti RJ, Calne DB, Stoessl AJ, Pfeiffer RF, Patenge N, Carbajal IC, Vieregge P, Asmus F, Muller-Myhsok B, Dickson DW, Meitinger T, Strom TM, Wszolek ZK, Gasser T. 2004. Mutations in LRRK2 cause autosomal-dominant parkinsonism with pleomorphic pathology. Neuron 44(4):601-607. 